\title{
Radiocarbon Ages for Two Sites on Ua Huka, Marquesas
}

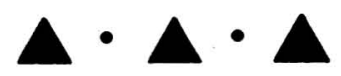

\author{
ERIC CONTE AND ATHOLL ANDERSON
}

Discussion ABOUt THE COLONIZATION ERA IN THE MARQUESAS has been dominated by reference to sites excavated during the 1950 s and 1960s, such as Hane, $\mathrm{Ha}$ 'atuatua, and Hanatekua. The two former sites have been reinvestigated chronologically (Anderson and Sinoto 2002; Rolett and Conte 1995), producing results indicating rather later occupation than was earlier envisaged. This is also true of Anapua (Leach et al. 1990), and since Hanamiai, dated to the eleventh century A.D. and later, appears to represent a colonization phase (Rolett 1998), it is pertinent to record two additional cases where circumstances suggested a potentially early age of occupation. These are Hatuana and Hokatu, both coastal sites on Ua Huka.

\section{HATUANA}

Hatuana Valley is located at the southwestern extremity of Ua Huka, close to a promontory used traditionally to watch for hostile parties from Nuku Hiva. As a result the vicinity may have been occupied continually or frequently through the prehistoric era. There is fresh water in Hatuana Valley and, in addition to the sand-dune sites, there are petroglyphs on the side and top of the promontory. These signs of settlement led Conte and Poupinet (1998) to explore the locality and test-excavate the sand dunes in two places in 1997.

Five test pits were excavated in the dunes that border the coast of the bay at two different places (Fig. 1). Test Pit 1 was near the beach front of a small dune (29-by-20 m) located against the hill slope, while the other four test pits were in another dune system located at the east end of the bay. Test Pits 2 and 3, on top of that dune, did not encounter deep stratigraphy, but Test Pits 4 and 5 on the front edge of the dune disclosed $2 \mathrm{~m}$ and $1.5 \mathrm{~m}$, respectively, of stratigraphy.

In 1997, Test Pit 1 (HAT-S1-1) revealed complex stratigraphy extending 180 $\mathrm{cm}$ in depth. From the deepest oven in it, at $140 \mathrm{~cm}$ in Layer I, a charcoal sample

Eric Conte is Maître de Conférences in Archaeology at the Université de la Polynésie Française and responsible of the Oceanian Prehistory courses at the Université Paris-1 (Panthéon-Sorbonne). Atholl Anderson is Professor of Prehistory in the Research School of Pacific and Asian Studies, and Director of the Centre for Archaeological Research, Australian National University. 


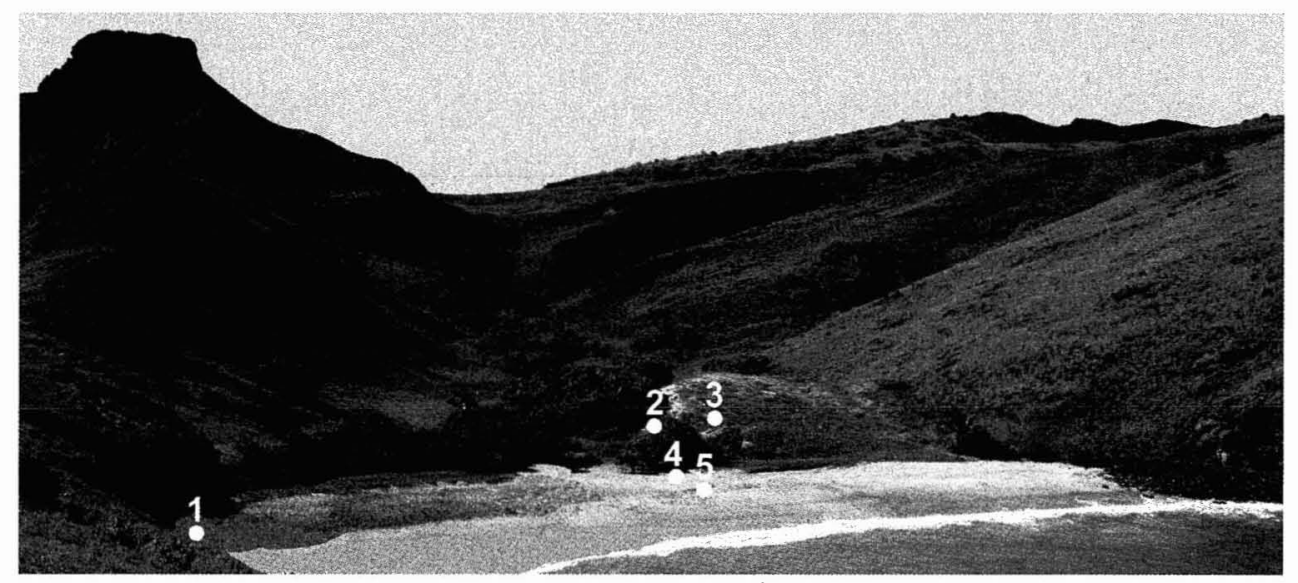

Fig. 1. Hatuana Bay showing the localities of the test pits.

returned a radiocarbon age indicating occupation during the sixth to seventh centuries A.D. (Beta-116139, Table 1). Two other results, from Test Pits 4 (HATS4-3) and 5 (HAT-S5-2), were rather later. Both are from the deepest layer encountered in each case but that in Test Pit 5, dated by Beta-116141, is regarded as stratigraphically lower than that in Test Pit 4, dated by Beta-116140. The CRA results are reversed, although they overlap substantially in calibration (Table 1). The earliest result, Beta-116139 from Test Pit 1, was tested by referring additional samples to other laboratories.

Test Pit 1 was reopened in 1999 (Fig. 2) and samples were taken from a section adjacent to that sampled in 1997 (Conte et al. 2001). There were some minor stratigraphic differences between the upper parts of the two sections, but the lower parts were effectively identical. At the base of both the 1997 and 1999 sections of Test Pit 1, there is a sand conglomerate that appears to represent a fossil beach (layer H, Fig. 2). Immediately above it, in the 1999 section, lies a sand layer containing some midden (bird and fish bone, shell), and an oven at 160-177 cm in depth. This layer was designated G in 1999 (Conte et al. 2001), but because it is continuous with and corresponds stratigraphically to layer I in the 1997 excavation, we have labeled it here G/I. The layer G/I oven, and a charcoal band at approximately $110 \mathrm{~cm}$ in depth, layer D (Fig. 2), were dated on charcoal samples at Waikato Radiocarbon Laboratory. The results, Wk-8057 and Wk-8058 respectively (Table 1), are much later than Beta-116139. Because that result and Wk8057 are from the same stratigraphic context (above), this left us with incompatible alternatives. An additional sample from the layer G/I oven was processed at the Oxford Radiocarbon Accelerator Laboratory, producing an age in support of the Waikato result (OxA-9766, Table 1).

\section{HOKATU}

Hokatu is on the southern coast of Ua Huka. It has a sheltered bay and is one of the three principal valleys that are still inhabited. The site was exposed during the excavation of a sewage pit by the people of Hokatu village. They reported char- 
Table i. Radiocarbon Dating Results for Sites at Hatuana and Hokatu on Ua Huka, Marquesas

\begin{tabular}{|c|c|c|c|c|c|c|}
\hline LABORATORY NO. & MATERIAL & $\begin{array}{l}\text { SAMPLE } \\
\text { WEIGHT (G) }\end{array}$ & PROVENIENCE & CRA (B.P.) & $\delta^{13} \mathrm{C} \%$ & $\begin{array}{l}\text { CALIBRATED AGE } \\
\text { (2-SIGMA) }\end{array}$ \\
\hline \multicolumn{7}{|l|}{ Hatuana } \\
\hline Beta-116139 & Charcoal & - & HAT-S1-1, Test Pit 1, 1997 & $1410 \pm 50$ & -24.5 & A.D. $575-690$ \\
\hline Beta-116140 & Charcoal & - & HAT-S4-3, Test Pit 4, 1997 & $1030 \pm 90$ & -24.9 & A.D. $855-1215$ \\
\hline Beta-116141 & Charcoal & - & HAT-S5-2, Test Pit 5, 1997 & $800 \pm 50$ & -24.1 & A.D. $1170-1290$ \\
\hline Wk-8057 & Charcoal & 1.6 & Layer G/I, oven, Test Pit 1, 1999 & $430 \pm 55$ & -25.6 & A.D. $1410-1640$ \\
\hline Wk-8058 & Charcoal & 1.7 & Layer D, Test Pit 1, 1999 & $380 \pm 31$ & -25.3 & A.D. $1300-2000$ \\
\hline OxA-9766 & Charcoal & 0.3 & Layer G/I, oven, Test Pit 1, 1999 & $390 \pm 31$ & -25.8 & A.D. $1430-1630$ \\
\hline \multicolumn{7}{|l|}{ Hokatu } \\
\hline Wk-8059 & Charcoal & 0.3 & Layer F: 1 & $860 \pm 60$ & -26.0 & A.D. $1030-1290$ \\
\hline Wk-8060 & Charcoal & 40.0 & Trench base & $890 \pm 50$ & -25.8 & A.D. $1020-1280$ \\
\hline
\end{tabular}

Note: Wk-8059 is an AMS age (NZA-11236). Calibrations are by the laboratories concerned. 


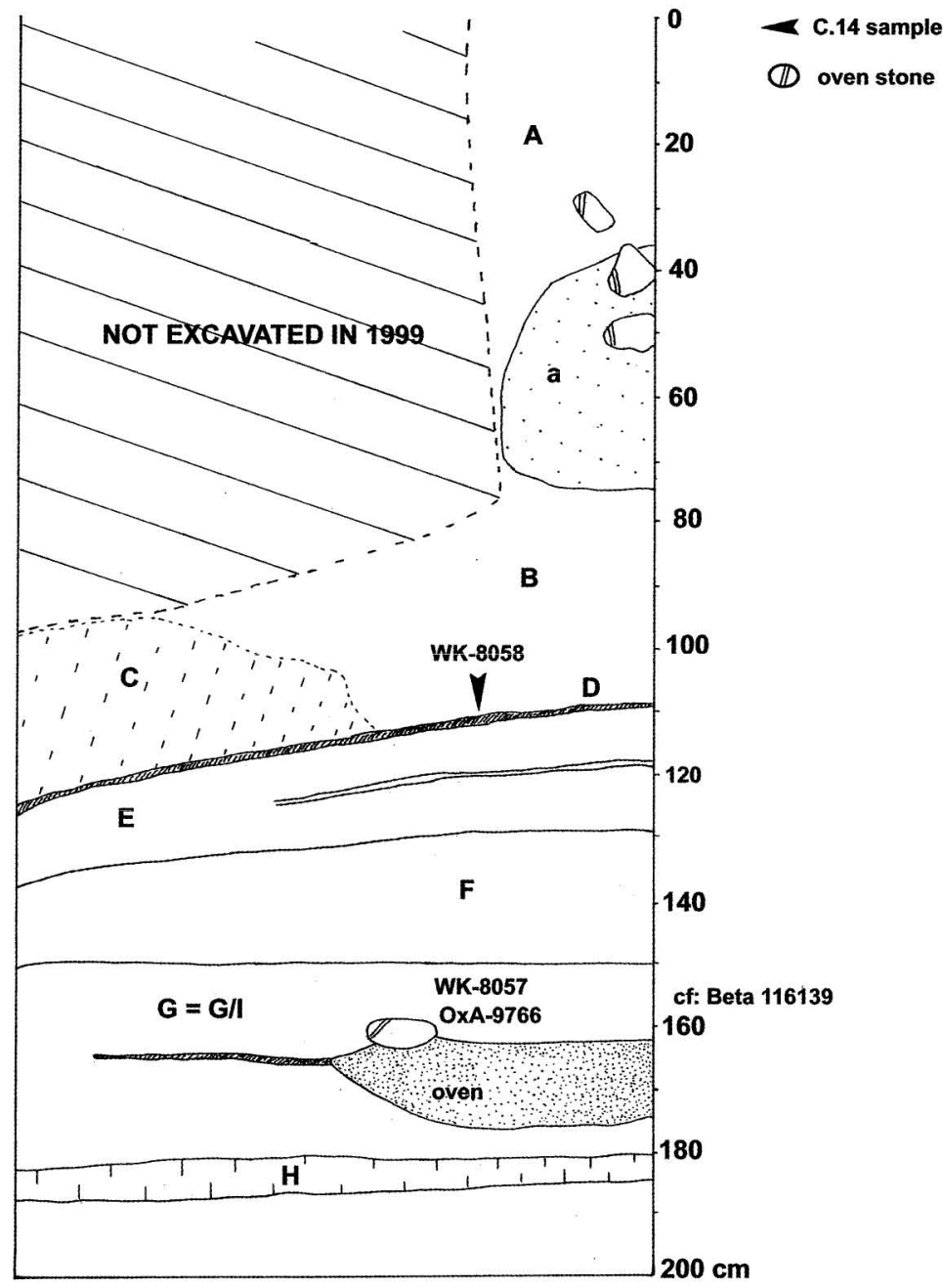

Fig. 2. The stratigraphy of Test Pit I (HAT-SI-I) at Hatuana Bay, 1999 section.

coal and ovens at a depth of $3 \mathrm{~m}$ below the ground surface in a coastal flat, a circumstance suggesting that the site might be relatively old. Some charcoal was retrieved from the lowest exposure and a second trench was opened adjacent to the first (Conte et al. 2001). Samples of turtle bone and charcoal from the lowest layers in the second trench, and charcoal from the lowest exposure in the first, were submitted to Waikato Radiocarbon Laboratory (Fig. 3). The turtle bone, from $250 \mathrm{~cm}$ in depth, was pretreated but proved to contain too little protein to permit an estimation of age and it was abandoned (Wk-8092). Charcoal from layer $\mathrm{F}$ at $250-265 \mathrm{~cm}$ in the second trench dated to the eleventh to thirteenth centuries A.D. (Wk-8059), as did a sample from the first trench (Wk-8060) (see Table 1). 


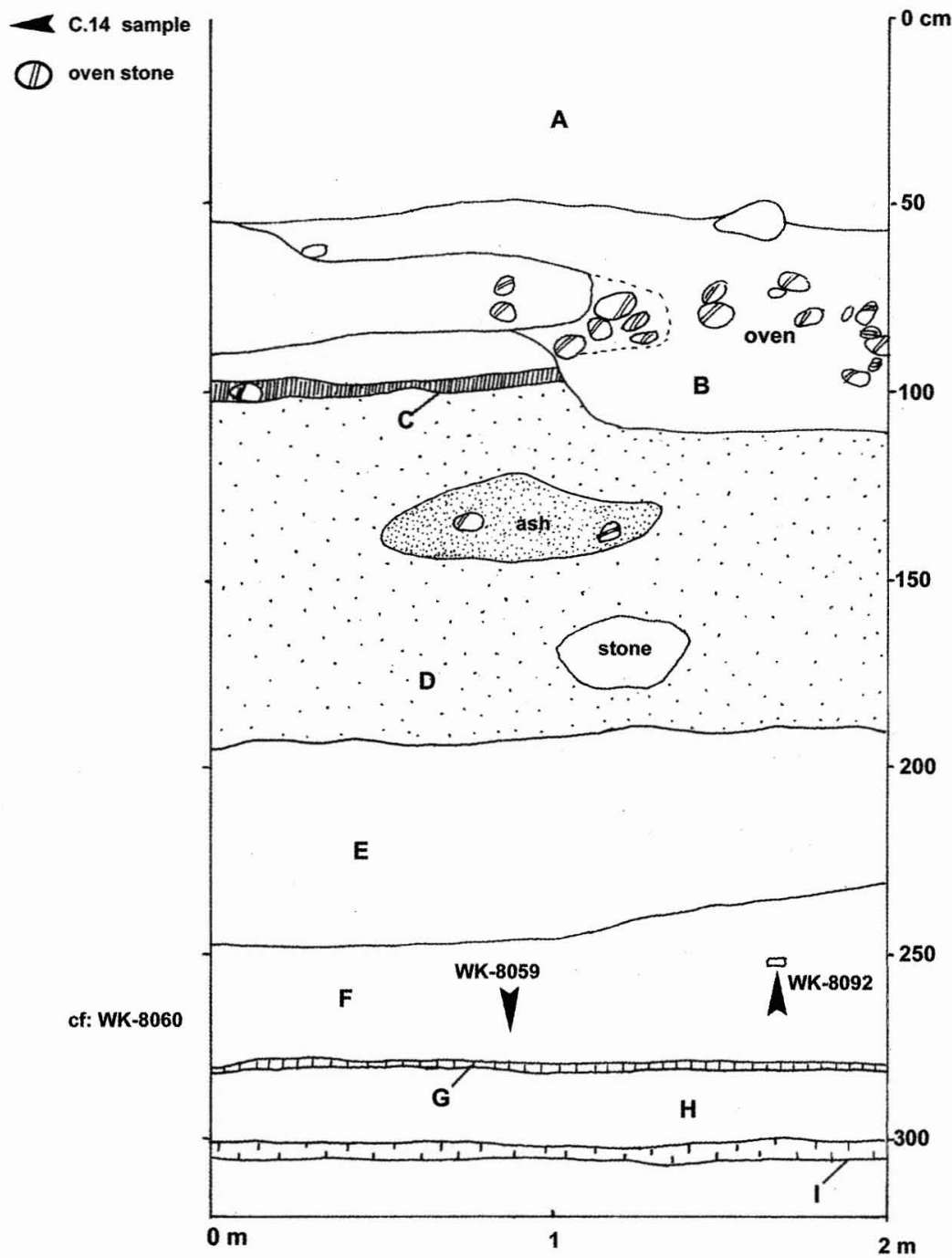

Fig. 3. The stratigraphy of the trench at Hokatu Bay.

\section{CONCLUSIONS}

Because none of the charcoal samples was identified to species, all of the dates reported here must be regarded as maximum ages. Nevertheless, the dates from Hokatu are quite plausible, indicating an early phase of occupation in Ua Huka, when they are compared with the latest results from Hane and other early sites in the Marquesas (Anderson and Sinoto 2002). The dates from Hatuana are more problematic. The difference between Beta-116139 and those from Waikato (Wk8057) and Oxford (OxA-9766) laboratories is considerable and near the margin of probability in terms of inbuilt age from old wood. Because the other two Beta results (Beta-116140 and Beta-116141) are also substantially older than expected 
in light of the 1999 results from Waikato and Oxford, some further testing is desirable.

In the interim, we note the plausibility of the results for Hokatu relative to other recent radiocarbon-age estimates for early sites in the Marquesas. In regard to Hatuana we prefer the later results, given the close correspondence in age estimation for layer G/I provided by two laboratories against the single older result. Taken as maximum estimates of age for the same stratigraphic context, the oldest result should be discarded.

\title{
ACKNOWLEDGMENTS
}

We thank Tom Higham and Fiona Petchey, Waikato Radiocarbon Laboratory, for advice and assistance.

\section{REFERENCES CITED}

Anderson, A., AND Y. Sinoto

2002 New radiocarbon ages for colonization sites in East Polynesia. Asian Perspectives 41(2): 242-257.

Conte, Eric, And Y. Poupinet

1998 Etude Paleoécologique et archéologique de l'île de Ua Huka (Archipel des Marquises-Polynésie française), Campagne 1997. Faaa: Universite de la Polynesie française.

Conte, E., A. Noury, and N. Tartinville.

2001 Recherche ethnoarchéologique a Ua Huka (Marquises-Polynésie française). Campagne 1998-99. Faaa: Universite de la Polynésie française.

Leach, B. F., M. Horwood, R. Mcgovern-Wilson, I.W.G. Smith, P. Ottino, and M. N. OTTINO

1990 Analysis of faunal material from Te Ana Pua, Ua Pou, Marquesas Islands. Unpublished technical report, National Museum of New Zealand.

ROLETT, B.V.

1998 Hanamiai. Prehistoric Colonization and Cultural Change in the Marquesas Islands (East Polynesia). Yale University Publications in Anthropology 88. New Haven: Department of Anthropology and the Peabody Museum, Yale University.

Rolett, B. V., And E. Conte

1995 Renewed investigation of the Ha'atuatua dune (Nuku Hiva, Marquesas Islands): A key site in Polynesian prehistory. Journal of the Polynesian Society 104(2): 195-228.

\begin{abstract}
Radiocarbon dates are presented and discussed for two sites with deep stratigraphy on Ua Huka Island, Marquesas. The lowest layer at the Hokatu site dates to the eleventh to thirteenth centuries A.D. At Hatuana, earlier radiocarbon-age estimates extended to the sixth to ninth centuries A.D. New results from the Waikato and Oxford Radiocarbon laboratories indicate that the lower levels at Hatuana are no older than about the fourteenth century. KEYwords: radiocarbon dates, East Polynesia, Marquesas, French Polynesia, archaeology.
\end{abstract}

